\title{
Reproductive biology of the sesarmid crab Armases rubripes (Decapoda, Brachyura) from an estuarine area of the Sahy River, Sepetiba Bay, Rio de Janeiro, Brazil
}

\author{
Giovana V. Lima ${ }^{1}$, Marcelo R. S. Soares² \& Lídia M.Y. Oshiro²
}

1. Pós-graduação em Biologia Animal, Universidade Federal Rural do Rio de Janeiro.

2. Estação de Biologia Marinha, Universidade Federal Rural do Rio de Janeiro, Rua Sereder, s/nº, Itacuruçá, 23880-000 Mangaratiba, RJ, Brasil. (oshiro@ufrrj.br)

\begin{abstract}
The aim of this work was to gain knowledge about reproductive biology of the crab Armases rubripes (Rathbun, 1897) from an estuarine area of the Sepetiba Bay. Samples were taken monthly from February 2003 to January 2004 in the Sahy River estuary $\left(22^{\circ} 56^{\prime} \mathrm{S} ; 44^{\circ} 01^{\prime} \mathrm{W}\right)$, Rio de Janeiro, Brazil. The crabs were collected by hand during 15 -minute catch-effort sessions conducted by two people. In the laboratory, the specimens were separated by sex, carapace width was measured and gonadal stage was checked macroscopically. A total of 830 individuals were caught - 304 males, 373 females (60 ovigerous females) and 153 juveniles. The ovigerous females were found almost year-round, except in November and April, showing a continuous reproductive period. They presented a size range from 8.2 to $15.0 \mathrm{~mm}$ carapace width $(12.1 \pm 1.7 \mathrm{~mm})$. Color and macroscopical aspects determined five gonadal stages for males and females (immature, rudimentary, intermediary, developed and resting). First sexual maturity was estimated at $6.5 \mathrm{~mm}$ of carapace width for males and $8.1 \mathrm{~mm}$ for females. Individual fecundity varied from 200 to 11,460 eggs $(4,458 \pm 2,739$ eggs $)$. Mean egg size was $0.248 \pm 0.026 \mathrm{~mm}$, varying from 0.213 to $0.333 \mathrm{~mm}$, while the volume ranged from 0.0051 to $0.0188 \mathrm{~mm}^{3}\left(0.0082 \pm 0.0029 \mathrm{~mm}^{3}\right)$.
\end{abstract}

KEYWORDS. Crab, Sesarmidae, fecundity, reproduction, sexual maturity.

RESUMO. Biologia reprodutiva do caranguejo sesarmídeo Armases rubripes (Decapoda, Brachyura) de uma área estuarina do rio Sahy, Baía de Sepetiba, Rio de Janeiro, Brasil. O objetivo desse trabalho foi obter informações sobre a biologia reprodutiva do caranguejo Armases rubripes (Rathbun, 1897) numa área estuarina da Baía de Sepetiba. Exemplares foram obtidos mensalmente de fevereiro 2003 a janeiro 2004 no estuário do rio Sahy $\left(22^{\circ} 56^{\prime} \mathrm{S}\right.$; $\left.44^{\circ} 01^{\prime} \mathrm{W}\right)$, Rio de Janeiro, Brasil. Os caranguejos foram coletados manualmente durante 15 minutos por estação de coleta e por dois coletores. Em laboratório, os indivíduos foram separados por sexos, mensurados em relação à largura da carapaça e os estágios gonadais observados macroscopicamente. Um total de 830 indivíduos foram obtidos - 304 machos, 373 fêmeas (60 fêmeas ovígeras) e 153 juvenis. As fêmeas ovígeras foram encontradas durante todo o período de estudo, exceto em novembro e abril, demonstrando um período reprodutivo contínuo. $\mathrm{O}$ tamanho das fêmeas ovígeras variou entre 8,2 e $15,0 \mathrm{~mm}$ de largura da carapaça $(12,1 \pm 1,7 \mathrm{~mm})$. As gônadas observadas apresentaram cinco estágios de desenvolvimento, de acordo com a coloração e o aspecto macroscópico (imatura, rudimentar, intermediária, desenvolvida e desovada). A maturidade sexual foi estimada aos $6,5 \mathrm{~mm}$ de largura da carapaça entre os machos e $8,1 \mathrm{~mm}$ entre as fêmeas. A fecundidade individual variou entre 200 e 11.460 ovos $(4.458 \pm 2.739$ ovos). O tamanho médio dos ovos foi de $0,248 \pm 0,026 \mathrm{~mm}$, variando entre 0,213 e $0,333 \mathrm{~mm}$, enquanto o volume variou entre 0,0051 e $0,0188 \mathrm{~mm}^{3}\left(0,0082 \pm 0,0029 \mathrm{~mm}^{3}\right)$.

PALAVRAS-CHAVE. Caranguejo, Sesarmidae, fecundidade, reprodução, maturidade sexual.

Crustaceans exhibit various patterns of life history and reproductive strategies, mainly when habitat is considered. According to Mantelatto \& FRANSOZO (1997), fecundity is an important parameter in determining the reproductive potential of a crustacean species and/or of stock size of a population. González-Gurriarán \& Freire (1985) related the importance of sexual maturity for estimating the puberty molt for the examination of external morphological modifications and gonads development.

The sesarmid crab Armases rubripes (Rathbun, 1897) is a tropical and subtropical species usually found in salt marshes and estuaries of Central and South America (CAPítoli et al., 1977), widely distributed from Nicaragua to Rio de la Plata, between Uruguay and Argentina (Melo, 1996).

According to CAPítoli et al. (1977), Fischer et al. (1997) and TEIXEIRA \& SÁ (1998), these small crabs feed on vegetable debris, mainly roots and stems of Spartina sp. (Poaceae), living inside self-built burrows in muddy substrates or between bromeliad axils.
Aspects concerning to biology of this species are restricted to a few studies. CAPítoli et al. (1977) studied this species in the estuarine region of Lagoa dos Patos, Rio Grande do Sul (Brazil); FISCHER et al. (1997) observed the consumption of bromeliad flowers at Juréia Ecological Station, in São Paulo (Brazil); TeIXEIRA \& SÁ (1998) related the importance of the bromeliad Aechmea blanchetiana (Baker) for this small crab, in Conceição da Barra, Espírito Santo (Brazil); CASTIGLIONI et al. (2004) described some reproductive aspects from different mangroves of the São Paulo coast.

As a contribution to the knowledge of this crustacean, some aspects of the reproductive biology of A. rubripes from an estuarine area were examined (e.g. sexual maturity, breeding period, molting, fecundity and eggs size).

\section{MATERIAL AND METHODS}

Sampling was performed monthly from February 2003 to January 2004 at the Sahy River estuary (22 $56^{\prime}$ 'S; 
$\left.44^{\circ} 01^{\prime} \mathrm{W}\right)$, Rio de Janeiro, Brazil. Crabs were collected by hand among grass and under organic substrates during low tide. Sampling consisted of 15-minute catch-effort sessions conducted by two collectors.

After their collection, A. rubripes specimens were packaged in plastic bags and frozen at $-5^{\circ} \mathrm{C}$. All crabs were sexed and presence or absence of eggs in the females was recorded. The carapace width $(\mathrm{CW})$ of each crab was measured using an ocular micrometer. The crabs were grouped into nine size classes from 0.1 to $18.0 \mathrm{~mm} \mathrm{CW}$. The reproductive season was obtained by analyzing the monthly relationship between ovigerous females and total mature females and comparing with mature gonads (recorded each month).

Molt stages were identified following the characteristics used by DRACH \& TCHERNIGOVTZEFF (1967) and Mantelatto \& Fransozo (1999). Two categories were recognized: intermolt (exoskeleton completely calcified) and molt (exoskeleton in initial post-molt, intermediate post-molt, advanced post-molt or pre-molt).

Gonads were examined to determine the size at which half of the population was physiologically mature $\left(\mathrm{CW}_{50 \%}\right)$. Stage of gonadal development was assigned by gonads color, shape and size (Tab. I). Five stages were considered: immature, rudimentary, intermediary, developed and resting. Individuals with immature gonads were classified as juveniles, while specimens with other aspects were considered adults.

The egg mass was carefully removed from the pleopods using tweezers and put in a $100 \%$ sodium hypochlorite solution for about five seconds and then washed in running water. The eggs were placed in a 50$\mathrm{ml}$ beaker and filled with seawater. Five 1-ml subsamples, with reposition, were obtained from the total sample. Each subsample was counted using a stereoscopic microscope and a manual counter. Egg diameter was determined using an ocular micrometer before their separation in sodium hypochlorite. Volume was determined using the equation $\mathrm{V}=1 / 6 \pi \mathrm{d}^{3}(\mathrm{~V}=$ volume and $\mathrm{d}=$ diameter $)$.

The stages (I and II) and substages (A, B, C, D and E) of embryonic development were classified according to the following criteria: stage I was represented by females bearing eggs without eye pigmentation (substage $\mathrm{A}=$ zygote and cleavage or homogeneous mass; substage $\mathrm{B}=$ eggs $90 \%$ filled with yolk and initiation of germinial disc) and stage II corresponded to females carrying eggs with eye pigment visible (substage $\mathrm{C}=$ compound eyes could be observed using a microscope and $60 \%$ filled with yolk; substage $\mathrm{D}=$ eye development in a darkened irregularly-rounded area, many chromatophore pigments on abdomen and 40-50\% filled with yolk; substage $\mathrm{E}=$ developed zoea).

Temperature and salinity of the water surface were measured monthly during the period of this study, and the correlation between the proportion of ovigerous females and these environmental factors was tested using Spearman's correlation analysis $(\alpha=0,05)$ (ZAR, 1996).

The reproductive period was determined analyzing the proportion of ovigerous females in the population throughout the year. Goodman's test was used to compare the number of ovigerous females among the studied months. The same test was used to analyze the association between molt stages and gonad maturation.

The Kruskal-Wallis test was used for comparing egg size along the different embryonic stages. In all statistical analyses, a 5\% significance level was chosen (ZAR, 1996).

\section{RESULTS AND DISCUSSION}

During the study, 830 specimens of $A$. rubripes were analyzed from which 153 were juveniles, 304 males and 373 females (60 ovigerous).

Ovigerous and mature females occurred almost every month, suggesting reproductive activity of the species almost year-round. Ovigerous females were absent in June and November, showing higher percentages in the summer (December, January and February) and in the first month of autumn (March), reducing their percentages over the other months (Fig. 1 ), suggesting a seasonal-continuous reproduction (PinheIro \& Fransozo, 2002). These authors suggested a reclassification of the breeding season proposed by SASTRY (1983) for crustaceans. Reproduction is considered continuous when ovigerous individuals and/ or females bearing mature gonads are present year-round with similar monthly frequencies throughout. If breeding is still recorded over the entire year, but monthly frequency of reproducing females varies with recognizable periods of higher reproductive activity, then seasonalcontinuous reproduction would apply. If the presences of ovigerous specimens and/or females with mature gonads are restricted to a determined period or season, then seasonal reproduction may be used.

Table I. Armases rubripes (Rathbun, 1897) from Sahy River estuary: characteristics of the five gonadal stages of males and females.

\begin{tabular}{lll}
\hline Stage & \multicolumn{2}{c}{ Characteristics } \\
\cline { 2 - 3 } $\begin{array}{lll}\text { Immature } & \text { Gonads undifferentiated } & \text { Females } \\
\text { Intermediary A } & \text { Vas deferens can be observed (appears filamentous) } & \text { Yellow ovary can be observed (appears filamentous) } \\
\text { Intermediary B } & \text { Vas deferens translucent, a little entwined } & \text { Arms and ovary connection are clear, beginning of } \\
\text { Developed } & \begin{array}{l}\text { Fully developed gonads; vas deferens whitish } \\
\text { (appears completely entwined) }\end{array} & \text { maturation; bright-orange colored } \\
\text { Resting } & & \text { Fully developed gonads; ovary brown colored and lobed }\end{array}$ \\
\hline
\end{tabular}


Armases angustipes (Dana, 1852) in Ilha do Farol, Paraná, Brazil, showed a seasonal reproductive period (spring to autumn) with a peak in October-November (KowAlCZUK \& MASUNARI, 2000).

Discernible frequency peaks of ovigerous females over this time are usual among some species of Grapsioidea, with breeding extension occurring the entire year: Aratus pisonii (H. Milne-Edwards, 1837), studied by Warner (1967), LeME \& NEgREIROS-Fransozo (1998) and Nicolau \& Oshiro (2002); Cyclograpsus punctatus H. Milne-Edwards, 1837, by Broekhuysen (1941); Pachygrapsus transversus (Gibbes, 1850), by ABELE et al. (1986) and Flores \& NEGREIROS-FransOzo (1998); Goniopsis cruentata (Latreille, 1803), by SiLva \& Oshiro (2002) and CoBo \& Fransozo (2003). According to Thorson (1950) and SASTRY (1983), notable frequency peaks of ovigerous females are generally associated to variations in environmental factors such as temperature, latitude, photoperiod, intertidal zonation and larval food availability.

Surface water temperature ranged from 23.5 to $30.0^{\circ} \mathrm{C}$ $\left(27.0 \pm 2.7^{\circ} \mathrm{C}\right)$, while the salinity ranged from 0 and 30.0 ppm $(13.0 \pm 10.0)$. Among the evaluated environmental factors, variations in water temperature and salinity did not show correlation with the presence of ovigerous females (Pearson's linear correlation, $r=0.5241, \mathrm{p}>0.05$; $\mathrm{r}=0.5708, \mathrm{p}>0.05)$.

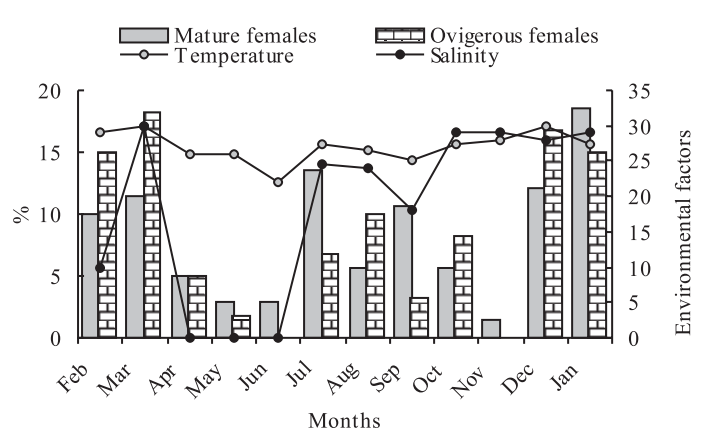

Fig. 1. Armases rubripes (Rathbun, 1897) from Sahy River estuary: relationship between reproductive period and environmental factors.

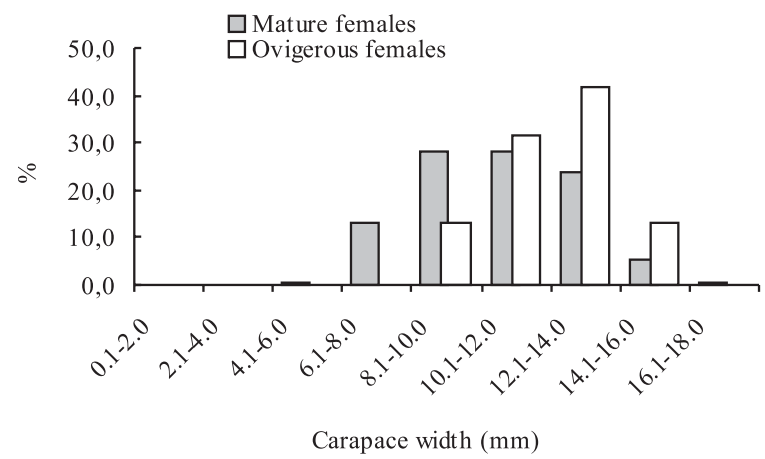

Fig. 2. Armases rubripes (Rathbun, 1897) from Sahy River estuary: frequency distribution of carapace width of mature females and ovigerous females.
According to COBO \& FrANSOZO (2003), the correlation of environmental factors was evident in the duration of the breeding period in G. cruentata. Water and air temperature, as well as photoperiod, were the most important variables that determined the breeding seasons. Temperature acts as a catalytic agent. It may accelerate physiological mechanisms and is probably associated with the development of gonadal tissues in these animals (ADIYODY \& ADIYODY, 1970; WEAR, 1974), whereas water temperature acts over the larval phases (Boolootian et al., 1959).

Female size distribution was comprised of size classes from 4.1 - 6.0 to 16.1 - $18.0 \mathrm{~mm}$ of carapace width. The mean size of ovigerous females was $12.1 \pm 1.7 \mathrm{~mm}$ of carapace width, ranging from 8.2 to $15.0 \mathrm{~mm}$ (Fig. 2).

Seasonality of molting in $A$. rubripes was not readily discernible. Specimens in molt and intermolt stages were observed during the entire sampling period (Fig. 3), except in November, when the molting females were absent.

The percentage of females with mature gonads was lower than $25.0 \%$ throughout the study. Mature gonad stages were present in every month, except the resting in June, intermediary in April, May, August, September and November and developed in February and November (Fig. 4 ). The total of ovigerous females obtained in this study showed resting stage gonads and the carapace in the intermolt period.

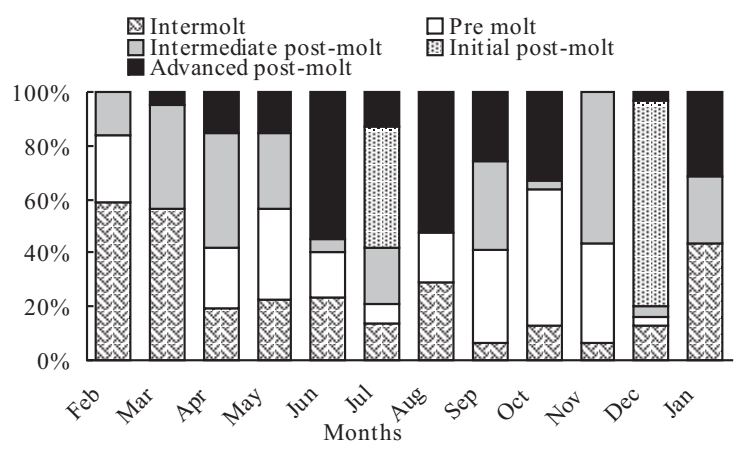

Fig. 3. Armases rubripes (Rathbun, 1897) from Sahy River estuary: monthly frequency of females with molt and intermolt stages.

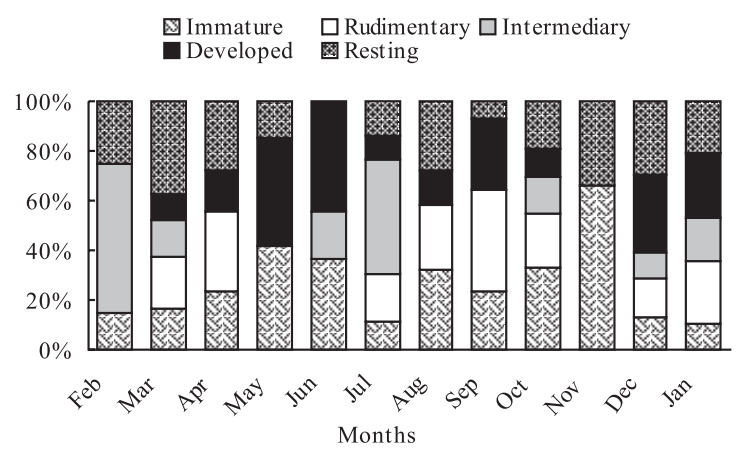

Fig. 4. Armases rubripes (Rathbun, 1897) from Sahy River estuary: distribution of female gonadal stages. 
Leme \& Negreiros-Fransozo (1998), in A. pisonii, and Castiglioni \& Santos (2001), in Cyrtograpsus angulatus Dana, 1851, recorded the presence of ovigerous females with developing gonads during embryonic growth, suggesting that they are able to spawn more than one egg mass in one reproduction season, characterizing the presence of multiple spawns.

In the present study, during laboratory observations, some ovigerous females released a new extrusion of eggs without molt occurrence. In addition, ovigerous females presented ovaries in different stages of development when they were separated for histology preparation, indicating that $A$. rubripes also has multiple spawns.

The production of mature gonad crabs during the entire year, as well as in this study, allows to infer that the interruptions or oscillations in each stage were associated to the environmental variations, which can adversely affect the survival of planktonic larvae, could delay egg extrusion and, consequently, to reduce the frequency of ovigerous females during these periods (Сово \& FRANSOZO, 2003).

Estimated mean size of first sexual maturity was $\mathrm{CW}_{50 \%}=6.5 \mathrm{~mm}$ carapace width for males and $\mathrm{CW}_{50 \%}=8.1$ $\mathrm{mm}$ for females. All individuals larger than $12.1 \mathrm{~mm}$ were mature (Fig. 5).

According to Masunari \& Dubiaski-Silva (1998), females attain the sexual maturity after males, probably because they need a more developed abdomen to allow greater support and ensure the moisture for the eggs during incubation. In contrast, $A$. rubripes obtained from different mangroves from the state of São Paulo presented males with the greatest size at morphological maturation (CAstiglioni et al., 2004).

Fecundity ranged from 200 to 11,460 eggs, whereas the mean was $4,458 \pm 2,739$ eggs. These values correspond to the lower crab with $12.5 \mathrm{~mm}$ of carapace width and the higher one with $14.8 \mathrm{~mm}$. The relationship between crab size and number of eggs may be expressed by the equation: $F=1007.6 \mathrm{CW}-7708.2\left(\mathrm{r}^{2}=0.409, \mathrm{n}=61\right)$, where $\mathrm{F}=$ individual fecundity (Fig. 6).

According to Hines (1982), Henmi (1989) and CASTIGLIONI \& SANTOS (2001), the great variation in number of eggs within the same size class can be explained by a series of factors such as individual variation in egg production, seasonal variation in food availability, multiple spawns, temperature, salinity, light, pressure of parasites and predators. According to RufFino et al. (1994), the abrasion while the animal moves around or ventilates, and the volumetric expansion of the eggs due to imbibitions of water at the initial and terminal periods of incubation, also explained these differences in the number of eggs for the different sizes of females. Balsundaran \& PANDiAn (1982) related that Decapoda species lose up to $43 \%$ of eggs exposed on pleopods.

Armases rubripes presented a reduced fecundity rate compared to other species of Grapsoidea (Tab. II), but presented higher rate compared to the fecundity obtained in the seven mangroves of São Paulo (CAstiglioni et al., 2004).

Egg diameter underwent a significant increase throughout the stages and sub stages $(p<0.05)$ (Tab. III). Mean diameter was $0.248 \pm 0.026 \mathrm{~mm}$, ranging from 0.213 to $0.333 \mathrm{~mm}$, whereas the volume was $0.0082 \pm 0.0029$ $\mathrm{mm}^{3}$, ranging from 0.0051 to $0.0188 \mathrm{~mm}^{3}$. From a total of 59 ovigerous females, $71.2 \%$ carried eggs in stage I, while $28.8 \%$ carried them in stage II.

Egg size variability has been attributed to the variation in the female size or age (STELLA et al., 1996) and genetic factors (MASHIKO, 1992). According to GiMÉNEZ \& ANGER (2001), salinity shows greater influence during the development of the eggs, which increase in size and reach their maximum a few days before hatching; at low salinities, the embryos develop more slowly. Although in this study salinity did not show correlation with the presence of ovigerous females, the Sahy River estuary is a stress area with values of salinity ranged from 0 to 30.0 ppm, which can directly influence egg size. The crab Chasmagnathus granulata (Dana, 1851) reacts similarly (RufFino et al., 1994).

According to Ruffino et al. (1994), Chasmagnathus granulata has a nearly constant egg diameter in all stages of development, ranging from 0.29 to $0.50 \mathrm{~mm}$, with a mean diameter of about $0.36 \pm 0.05 \mathrm{~mm}$. Thus, it has a shorter size compared to $A$. rubripes. This constant size during egg development probably occurs due to higher yolk reserves and passive physical changes at lower salinities (GIMÉNEZ \& ANGER, 2001).

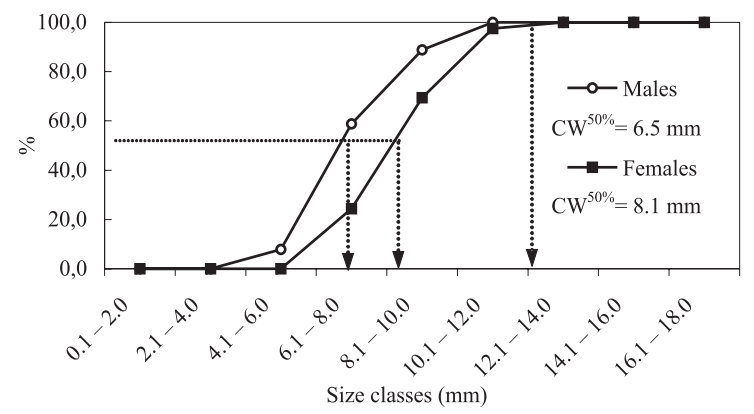

Fig. 5. Armases rubripes (Rathbun, 1897) from Sahy River estuary: the first sexual maturity for males and females.

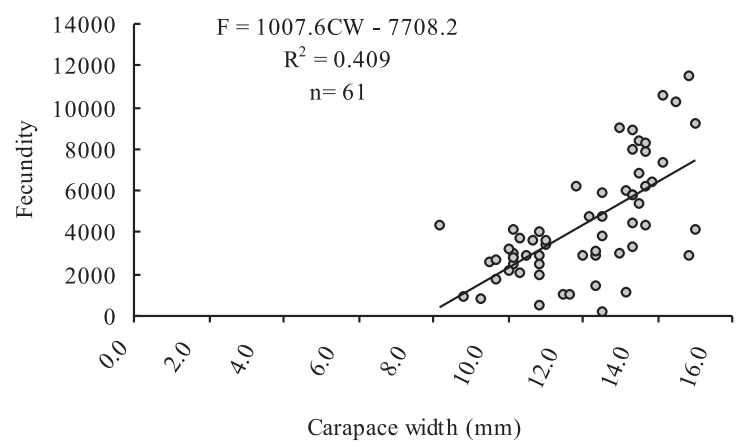

Fig. 6. Armases rubripes (Rathbun, 1897) from Sahy River estuary: relationship between number of eggs (fecundity) and carapace width. 
Table II. Comparisons of fecundity mean of the crab Armases rubripes (Rathbun, 1897) and other species of Grapsoidea (* the highest mean fecundity registered in different areas from São Paulo State).

\begin{tabular}{|c|c|c|c|c|}
\hline Species & Authors & Locality & Mean size $(\mathrm{mm})$ & Mean number of eggs \\
\hline \multirow[t]{2}{*}{ Aratus pisonii } & LEME \& NegREIROS-Fransozo (1998) & São Paulo & 18.7 & 15,197 \\
\hline & Nicolau \& Oshiro (2002) & Rio de Janeiro & 23.6 & 9,081 \\
\hline Cyrtograpsus angulatus & CAstiglioni \& SAntos (2001) & Rio Grande do Sul & 26.2 & 27,851 \\
\hline \multirow[t]{2}{*}{ Pachygrapsus transversus } & CAMpos \& OshiRo (2001) & Rio de Janeiro & 28.0 & 1,770 \\
\hline & Ogawa \& Rocha (1976) & Ceará & 10.6 & 9,222 \\
\hline Chasmagnathus granulata & RufFino et al. (1994) & Rio Grande do Sul & 16.5 & 19,250 \\
\hline \multirow[t]{2}{*}{ Goniopsis cruentata } & CoBo \& Fransozo (1998) & São Paulo & 18.7 & 15,197 \\
\hline & SiLva \& Oshiro (2002) & Rio de Janeiro & 35.1 & 74,751 \\
\hline \multirow[t]{4}{*}{ Armases rubripes } & CAPítoli et al. (1977) & Rio Grande do Sul & 11.7 & 3,790 \\
\hline & TEIXEIRA \& SÁ (1998) & Espírito Santo & 18.0 & 11,766 \\
\hline & CAstiglioni et al. (2004) & São Paulo & - & $3,526 *$ \\
\hline & Present study & Rio de Janeiro & 12.0 & 4,458 \\
\hline
\end{tabular}

Table III. Armases rubripes (Rathbun, 1897) from Sahy River estuary: mean size of eggs according to the embryonic development.

\begin{tabular}{ccccc}
\hline $\begin{array}{c}\text { Stages of embryonic } \\
\text { development }\end{array}$ & $\begin{array}{c}\text { Sub stages of embryonic } \\
\text { development }\end{array}$ & $\begin{array}{c}\text { Number of ovigerous } \\
\text { females }\end{array}$ & $\begin{array}{c}\text { Mean size of } \\
\text { eggs }(\mathrm{mm})\end{array}$ & $\begin{array}{c}\text { Volume } \\
\left(\mathrm{mm}^{3}\right)\end{array}$ \\
\hline I & A & 29 & $0.2361 \pm 0.143$ & $0.0070 \pm 0.0013$ \\
I & B & 13 & $0.2346 \pm 0.0109$ & $0.0068 \pm 0.0010$ \\
II & C & 3 & $0.2633 \pm 0.0176$ & $0.0096 \pm 0.0019$ \\
II & D & 8 & $0.2763 \pm 0.0289$ & $0.0114 \pm 0.0038$ \\
II & E & 6 & $0.2861 \pm 0.0262$ & $0.0125 \pm 0.0036$ \\
\hline
\end{tabular}

Acknowledgements. The authors are thankful to the Fundação de Amparo à Pesquisa no Estado do Rio de Janeiro (FAPERJ) for provide the financial support, as a fellowship during the first author's Doctoral Course.

\section{REFERENCES}

Abele, L. C.; Campanella, P. J. \& Salmon, M. 1986. Natural history and social organization of the semiterrestrial grapsid crab Pachygrapsus transversus (Gibbes). Journal of Experimental Marine Biology and Ecology 104:153-170.

Adiyodi, K. G. \& Adiyodi, R. G. 1970. Endocrine control of reproduction in Decapoda Crustacea. Biological Reviews 45: $121-165$.

Balsundaran, C. \& Pandian, T. J. 1982. Egg loss during incubation in Macrobrachium nobilii (Henderson \& Mathias). Journal of Experimental Marine Biology and Ecology 59(2,3):289-299.

Boolootian, R. A. A.; Giese, A. C.; Farmanfarmain, A. \& Tucker, J. 1959. Reproductive cycles of five west coast crabs. Physiological Zoology 32:213-220.

Broekhuysen, G. J. 1941. The life history of Cyclograpsus punctatus, M. Edw.: breeding and growth. Transaction of the Royal Society of South Africa 28:331-366.

Campos, D. A. \& Oshiro, L. M. Y. 2001. Biologia reprodutiva do caranguejo Pachygrapsus transversus (Gibbes, 1850) (Crustacea, Decapoda, Grapsidae) da Praia de Ibicuí-RJ. In: JoRnada de InICIAÇ̃̃o Científica da UFRRJ, $11^{\circ}$, Seropédica, 2001. Trabalhos Completos... Seropédica, Imprensa Universitária. v.11, n.2, p.209-212.

Capítoli, R. R.; Benvenuti, C. E. \& Gianuca, N. M. 1977. Ocorrência e observações bioecológicas do caranguejo Metasesarma rubripes (Rathbun) na região estuarina da Lagoa dos Patos. Atlântica 2(1):50-62.

Castiglioni, D. S. \& Santos, S. 2001. Reproductive aspects of Cyrtograpsus angulatus Dana, 1851 (Brachyura, Grapsidae) in the Lagoa do Peixe, Rio Grande do Sul State, Brazil. Nauplius 9(1):11-20.
Castiglioni, D. S.; Santos, S.; Reigada, A. L. D. \& NegreirosFransozo, M. L. 2004. Reproductive ecology of Armases rubripes (Sesarmidae) from mangroves of Southeastern Brazil. Nauplius 12(2): 109-117.

Cobo, V. J. \& Fransozo, A. 1998. Relative growth of Goniopsis cruentata (Crustacea, Brachyura, Grapsidae), on the Ubatuba Region, São Paulo, Brazil. Iheringia, Série Zoologia, 84:21-28. . 2003. External factors determining breeding season in the red mangrove crab Goniopsis cruentata (Latreille) (Crustacea, Brachyura, Grapsidae) on the São Paulo State Northern coast, Brazil. Revista Brasileira de Zoologia 20(2):213-217.

Drach, P. \& TchernigovtzefF, C. 1967. Sur la méthode de determination des stades d'intermue et son application genérale aux Crustacés. Vie et Milieu 18:596-610.

Fischer, E. A.; Duarte, L. F. L. \& Araújo, A. C. 1997. Consumption of bromeliad flowers by the crab Metasesarma rubripes in a Brazilian coastal forest. Crustaceana 70(1):118-120.

Flores, A. A. V. \& Negreiros-Fransozo, M. L. 1998. External factors determining seasonal breeding in a subtropical population of the shore crab Pachygrapsus transversus (Gibes, 1850) (Brachyura, Grapsidae). Invertebrate Reproduction and Development 34:149-155.

Giménez, L. \& ANGER, K. 2001. Relationships among salinity, egg size, embryonic development, and larval biomass in the estuarine crab Chasmagnathus granulata Dana, 1851. Journal of Experimental Marine Biology and Ecology 260:241-257.

GonzÁlez-Gurriarán, E. \& Freire, J. 1985. Reproducción de la nécora Macropipus puber (L.) (Decapoda, Brachyura), y ciclo reproductivo en la Ría de Arousa (Galicia, NW España). Boletin del Instituto Español del Oceanografia 2(1):10-32.

HenMi, Y. 1989. Reproductive ecology of three ocypodid crabs. II. Incubation sites and egg mortality. Ecological Research 4:261-269.

Hines, A. H. 1982. Allometric constrants and variables of reproductive effort in brachyuran crabs. Marine Biology 69:309-320. 
Kowalczuk, V. G. L. \& Masunari, S. 2000. Crescimento relativo e determinação da idade na fase juvenil de Armases angustipes (Dana) (Decapoda, Brachyura, Grapsidae). Revista Brasileira de Zoologia 17(1):17-24.

Leme, M. H. A. \& Negreiros-Fransozo, M. L. 1998. Fecundity of Aratus pisonii (Decapoda, Grapsidae) in Ubatuba Region, State of São Paulo, Brazil. Iheringia, Série Zoologia 84:73-77.

Mantelatto, F. L. M. \& Fransozo, A. 1997. Fecundity of the crab Callinectes ornatus Ordway, 1863 (Decapoda, Brachyura, Portunidae) from the Ubatuba Region, São Paulo, Brazil. Crustaceana 70(1):214-225.

1999. Reproductive biology and moulting cycle of the crab Callinectes ornatus (Decapoda, Portunidae) from the Ubatuba region, São Paulo, Brazil. Crustaceana 72(1):63-75.

Mashiko, K. 1992. Genetic egg and clutch size variations in freshwater prawn populations. Oikos 63:454-458.

Masunari, S. \& Dubiaski-Silva, J. 1998. Crustacea Decapoda da praia rochosa da Ilha do Farol. Matinhos, Paraná. II Distribuição espacial de densidade das populações. Revista Brasileira de Zoologia 15(3):643-664.

Melo, G. A. S. 1996. Manual de identificação dos Brachyura (caranguejos e siris) do litoral brasileiro. São Paulo, FAPESP, Museu de Zoologia. 603p.

Nicolau, C. F. \& Oshiro, L. M. Y. 2002. Aspectos reprodutivos do caranguejo Aratus pisonii (H. Milne Edwards) (Crustacea, Decapoda, Grapsidae) do manguezal de Itacuruçá, Rio de Janeiro, Brasil. Revista Brasileira de Zoologia 19(Supl. 2): $167-173$.

Ogawa, E. F. \& Rocha, C. A. S. 1976. Sobre a fecundidade de crustáceos decápodos marinhos do Estado do Ceará, Brasil. Arquivos de Ciências do Mar 16(2):101-104.
Pinheiro, M. A. A. \& Fransozo, A. 2002. Reproduction of the speckled swimming crab Aranaeus cribrarius (Brachyura: Portunidae) on the Brazilian coast near 2330'S. Journal of Crustacean Biology 22(2):416-428.

Ruffino, M. L.; Telles, M. D. \& D'Incao, F. 1994. Reproductive aspects of Chasmagnathus granulata Dana, 1851 (Decapoda, Grapsidae) in the Patos Lagoon estuary - Brazil. Nauplius 2:43-52.

Sastry, A. 1983. Ecological aspects of reproduction. In: Buiss, D. E. ed. The biology of Crustacea. New York, Academic. p. 179-269.

Silva, Z. S. \& Oshiro, L. M. Y. 2002. Aspectos reprodutivos de Goniopsis cruentata (Latreille) (Crustacea, Brachyura, Grapsidae) na Baía de Sepetiba, Rio de Janeiro, Brasil. Revista Brasileira de Zoologia 19(3):907-914.

Stella, V.; López, L. \& Rodríguez, E. 1996. Fecundity and brood biomass investment in the estuarine crab Chasmagnathus granulata Dana, 1851. Crustaceana 69:307-312.

TeIXeIRA, R. L. \& SÁ, H. S. 1998. The use of bromeliads as an alternative shelter by the grapsid crab, Metasesarma rubripes (Rathbun, 1897) of southeast Brazil. Boletim do Museu de Biologia Mello-Leitão 8:13-20.

Thorson, G. 1950. Reproductive and larval ecology of marine bottom invertebrates. Biological Reviews 25(1):1-45.

Warner, G. F. 1967. The life history of the mangrove tree crab, Aratus pisonii. Journal of Zoology 153:321-325.

Wear, R. G. 1974. Incubation in British decapod Crustacea, and the effects of the temperature on the rate and success of embryonic development. Journal of the Marine Biological Association of the United Kingdon 54:745-762.

ZAR, J. H. 1996. Biostatistical analysis. New Jersey, Prentice Hall. 1662p.

Recebido em fevereiro de 2005. Aceito em novembro de 2005. ISSN 0073-4721

Artigo disponível em: www.scielo.br/isz 